報文

\title{
シリカゲル担持炭酸銀を用いたテルペンアルコールと 臭化糖誘導体の反応によるテルペン配糖体の合成
}

\author{
宮腰 哲雄*・沼田 昭 \\ 明治大学理工学部工業化学科（勇 214 川崎市多摩区東三田 1-1-1)
}

Synthesis of Terpenyl $\beta-D-$ Glucopyranosides from Terpene Alcohols and

Tetra-O-acetyl $-\alpha-\mathrm{D}-$ glucopyranosyl Bromide with

Silver Carbonate Supported on Silica Gel

Tetsuo Miyakoshi* and Akira Numata

Department of Industrial Chemistry, School of Science and Technology, Meiji University

(Higashimita, Tama-ku, Kawasaki-shi, $\mathbf{T} 214$ )

\begin{abstract}
Terpenyl $\beta-D-$ glucopyranosides (3 $\mathbf{a}-\mathbf{e})$ were prepared from terpene alcohols $(2 \mathbf{a}-\mathbf{e})$ and tetra-O-acetyl- $\alpha-\mathrm{D}$-glucopyranosyl bromide (1) by a modification of Koenigs-Knorr procedure in the presence of silver carbonate supported on silica gel or alumina, followed by deacetylation. In this study terpenyl $\beta-D-$ glucopyranosides ( $3 \mathbf{a}-\mathbf{e}$ ) were obtained from geraniol (2 a), nerol (2 b), citronellol (2 c), cis-3-hexenol (2 d), menthol (2 e) and all-trans-retinol (2 f ) in relatively good yields. All-trans-retinyl $\beta-\mathrm{D}-$ glucuronide (5) was prepared in a similar manner from methyl 2,3,4-triacetyl-1-bromo-D-glucuronate (4) and all-trans-retinol (2 f) in 28 $\%$ yield.
\end{abstract}

\section{1 緒 言}

グリコシド結合を有する化合物は動植物界に広く存在 し，種々の生理活性を有する重要な糖誘導体も知られて (るる1)。油性のアルコールやフェノール類が、糖と $O-$ グリコシル化して得られる物質は不揮発性となり安定化 し，更に疎水性化合物が親水化されるなど物理・化学的 な性質が大きく変化する22。そのため種々の応用が考え られている3)。最近このような $O$ グリコシド類の新し い合成法が多数開発されている4)。一般にテルペン化合 物は，酸性条件下では環化反応や異性化反応が進行する ため，テルペンアルコールと糖のアセタート誘導体との 酸触媒を用いるグリコシル化反応は, テルペン配糖体の 合成には適さない。このような場合，銀化合物のような 重金属化合物を反応剂や活性化剂として用い，保護され たハロゲン化糖とアルコールから，中性条件下でグリコ シル化を進行させる Koenigs-Knorr 反応が用いられ る5)。この Koenigs-Knorr 反応を効率よく進めるた めに種々の重金属塩，また可溶性反応剂，添加物の影響

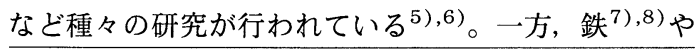

連絡者 : 宮腰哲雄
銀9),10)などの重金属化合物を用いる酸化反応におい て, 重金属化合物を単独に用いるよりもシリカゲルやセ ライトなどの固体に担持させて用いると生成物の収率や 選択性が向上したり, さらに反応生成物之酸化剂の分離 が容易になるなどの特徵が認められるため固体担持反応 剂や活性化剂の利用が種々検討されている。今回, 我々 は臭化糖誘導体 (1) と種々のテルペンアルコール (2) と の固体担持銀反応剂を用いた Koenigs-Knorr 反応を

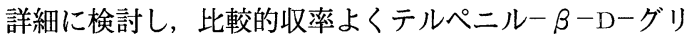
コシル化生成物（3）を得たので報告する。

\section{2 実 験}

\section{$2 \cdot 1$ 試料と試薬}

テトラーO-アセチル $-\alpha-\mathrm{D}-$ グルコピラノシル $=$ ブロ ミド (1) は, ペンタアセチルー $\beta-\mathrm{D}-$ グルコース ${ }^{11)}$ と $\mathrm{HBr}$-酢酸から合成した ${ }^{12)}$ (収率 $93 \%$ )。2,3,4-トリ アセチル-1-ブロモ-Dーグルクロン酸メチル (4) は， $\alpha$ -DーグルコースからテトラーO-アセチル-6-O-トリ フェニルメチルー $\beta-\mathrm{D}$-グルコピラノースを合成し（収 率 66 \%), これを過マンガン酸カリウムで酸化し，ジア ゾメタンでメチル化し，更に $\mathrm{HBr}$-酢酸でブロム化する 


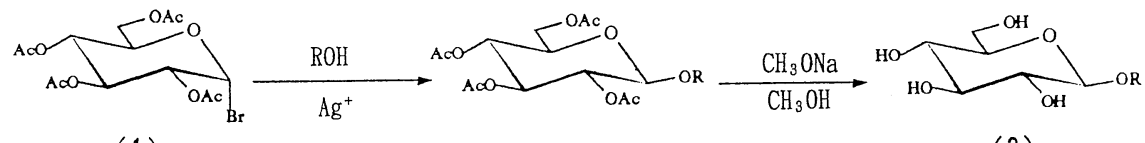

(1)

$$
\begin{array}{lll}
\mathrm{R} 0 \mathrm{H} \text { (2) } & \text { a } & \mathrm{R}=\text { Gerany } 1 \\
\text { b } & \mathrm{R}=\text { Nery } 1 \\
\text { c } & \mathrm{R}=\text { Citronel1y } 1 \\
\text { d } & \mathrm{R}=\text { cis-3-Hexeny } 1 \\
\text { e } & \mathrm{R}=\text { Menthy } 1 \\
\text { f } & \mathrm{R}=\text { Retiny } 1
\end{array}
$$

Scheme-1

ことにより合成した ${ }^{13}$ ）（全収率 $10 \%$ ）。all-transーレ チノール (2 f) は, 市販のレチニルパルミテートをメタ ノール中 $1 \%$ ナトリウムメトキシドを用いて加水分解 し, $\mathrm{H}^{+}$型カチオン交換樹脂 (ダイヤイオン $\mathrm{SR}-1 \mathrm{~B}$ ) で 中和し, メタノールを留去後シリカゲルカラムクロマト グラフィー $(n$-ヘキサン: 酢酸エチル $=7: 3)$ で精製し 得られた（収率 $60 \%$ )。得られたレチノールはプロト ンデカップリング法, ${ }^{1} \mathrm{H}-{ }^{1} \mathrm{H}$ COSY 及び NOESY NMR スペクトルなどを測定し，オールトランス型であ ることを確認した。その他の各試薬及び溶媒は, 市販の 一級試薬を GLC 分析や NMR スペクトルの測定によ り, 良質なものをそのままあるいは蒸留精製して使用し た。

\section{$2 \cdot 2$ 生成物の分析}

ガスクロマトグラフは Hewllet Packard 社製 5890 A を, カラムにはUltra-1 (0.32 mm i.d $\times 25 \mathrm{~m})$ キャ ピラリーカラムを用いて分析した。IR スペクトルは島 津 IR-435 型で測定した。NMR スペクトルは日本電子 社製 JEOL GSX 270 型を用いた。

\section{$2 \cdot 3$ 固体担持銀反応剂の調製}

\section{A シリカゲル担持炭酸銀反応剂の調製}

Fetizon らの方法 ${ }^{10)}$ を応用して硝酸銀 $3.4 \mathrm{~g}(20$ $\mathrm{mmol})$ を脱イオン水 $20 \mathrm{~mL}$ に溶かし, 100 200 mesh のカラムクロマト用シリカゲル $3.0 \mathrm{~g}$ を加えかき混ぜ た。これに炭酸ナトリウム $1.1 \mathrm{~g}(10.5 \mathrm{mmol})$ を脱イ オン水 $30 \mathrm{~mL}$ に溶かした水溶液をゆっくりと滴下し た。滴下後 $10 \mathrm{~min}$ かきまぜ, 黄緑色の懸濁液を吸引沪 過し, 水洗後, アセトン, トルエンで順次洗浄し, $50^{\circ} \mathrm{C}$ で減圧乾燥してシリカゲル担持炭酸銀反応剂を調製し た。このときの炭酸銀の担持率は $46 \mathrm{wt} \%$ であった。

担体としてアルミナ及びセライトを用い, 同様な方法 によりアルミナ及びセライト担持炭酸銀反応剂を調製し た。また固体担持酸化銀反応剤は塩基として水酸化ナト リウムを用いて調製した。

\section{B シリカゲル担持ケイ酸銀反応剂の調製 ${ }^{14)}$}

硝酸銀 $3.5 \mathrm{~g}(20.6 \mathrm{mmol})$ を脱イオン水 $20 \mathrm{~mL}$ に溶
かし, 100〜200 mesh のカラムクロマト用シリカゲル $3.0 \mathrm{~g}$ を加えかき混ぜた。これにケイ酸ナトリウム 10.6 $\mathrm{g}$ を脱イオン水 $10 \mathrm{~mL}$ に溶かした水溶液を加え, $70^{\circ} \mathrm{C}$ に加熱した。その後混合物を吸引沪過し，10\%ケイ酸 ナトリウム水溶液 $20 \mathrm{~mL}$ で洗浄し, さらにアセトン, トルエンで順次洗浄した後, $70^{\circ} \mathrm{C}$ で減圧乾燥してシリカ ゲル担持ケイ酸銀反応剂を調製した。

C サリチル酸銀反応剂の調製 15$)$

サリチル酸 $5.2 \mathrm{~g}(37.7 \mathrm{mmol})$ をエタノール $40 \mathrm{~mL}$ に溶かし, 水酸化ナトリウム $1.6 \mathrm{~g}(40.0 \mathrm{mmol})$ を少 量の脱イオン水に溶かした水溶液を加えよくかき混ぜ た。これに硝酸銀 $6.8 \mathrm{~g}(40.0 \mathrm{mmol})$ を $50 \%$ エ夕 ノール水溶液 $20 \mathrm{~mL}$ に溶かした溶液を加え, 析出した 白色沈殿を吸引沪過し, エ夕ノール, ジエチルエーテル で順次洗浄し, $50^{\circ} \mathrm{C}$ で減圧乾燥してサリチル酸銀反応剂 を調製した。

\section{$2 \cdot 4$ ゲラニオール (2 a) のグリコシル化反応例}

ゲラニオール (2 a) $239 \mathrm{mg}$ (1.55 mmol), テトラ -O-アセチル $-\alpha-$ グルコピラノシル $=$ ブロミド (1) $411 \mathrm{mg}(1.00 \mathrm{mmol})$, シリカゲル担持炭酸銀反応剂 $0.717 \mathrm{~g}\left(\mathrm{Ag}_{2} \mathrm{CO}_{3}: 1.20 \mathrm{mmol}\right)$, モレキュラーシブ $4 \mathrm{~A} 500 \mathrm{mg}$ をジエチルエーテル中室温で $10 \mathrm{~min}$ かき まぜた後, 加熱還流下 $3 \mathrm{~h}$ 反応させた。反応の進行を TLC で追跡した。反応後ジエチルエーテルで希釈し, 触媒を沃別し, 溶媒留去した。得られた反応混合物をメ タノール中 $1 \%$ ナトリウムメトキシドを用いて加水分 解し, $\mathrm{H}^{+}$型カチオン交換樹脂で中和し, メタノールを 留去後シリカゲルカラムクロマトグラフィー（クロロホ ルム : メタノール $=9: 1)$ で精製し，グリコシル化生成 物（3 a） $168 \mathrm{mg}$ (収率 $53 \%$ ）を得た。反応生成物の構 造は ${ }^{1} \mathrm{H}$ NMR, ${ }^{13} \mathrm{C} \mathrm{NMR},{ }^{1} \mathrm{H}-{ }^{1} \mathrm{H}$ COSY 及び ${ }^{1} \mathrm{H}-$ ${ }^{13} \mathrm{C}$ COSY スペクトルにより決定した。グリコシル化 生成物（3 a), ペルアセチルグリコシル化生成物及びオ ルトエステル体のそれぞれの TLC の $R f$ 值は次の通り である。 $R f=0.28,0.35$ 及び 0.05 。なおいずれの TLC 展開溶媒も $n$-ヘキサン : 酢酸エチル $=7: 3$ である。 


\section{ゲラニルー $\beta-\mathrm{D}-$ グルコピラノシド $(\mathrm{3} \mathrm{a})^{16)}$}

${ }^{1} \mathrm{H}-\mathrm{NMR}\left(\delta\right.$, methanol- $\left.\mathrm{d}_{4}\right): 1.61(3 \mathrm{H}, \mathrm{s}, 9-$ $\left.\mathrm{CH}_{3}\right), 1.68\left(6 \mathrm{H}, \mathrm{s}, 8,10-\mathrm{CH}_{3}\right), 2.09(4 \mathrm{H}, \mathrm{m}$, 4,5- $\mathrm{CH}_{2}$ ), $3.16(4 \mathrm{H}, \mathrm{m}, \mathrm{Glu}-2 \sim 5$ ), 3.65 3.89 (2 H, d. d, Glu-6), 4.21 4.38 (2 H, m, 1-CH), 4.29 ( $1 \mathrm{H}, \mathrm{d}, J=6.6 \mathrm{~Hz}, \mathrm{Glu}-1), 5.09(1 \mathrm{H}, \mathrm{t}, 6-\mathrm{C}=\mathrm{CH})$, $5.37(1 \mathrm{H}, \mathrm{t}, 2-\mathrm{C}=\mathrm{CH})$.

${ }^{13} \mathrm{C}-\mathrm{NMR}\left(\delta\right.$, methanol- $\left.\mathrm{d}_{4}\right): 17.26(10-\mathrm{C})$, 18.57 (9-C), 26.73 (8-C), 28.15 (4-C), 41.41 (5-C), $63.44(\mathrm{Glu}-6), 67.03(1-\mathrm{C}), 72.30(\mathrm{Glu}-4), 75.69$ (Glu-2), $78.62(\mathrm{Glu}-5), \quad 78.78(\mathrm{Glu}-3), \quad 103.35$ (Glu-1), 122.31 (2-C), 125.79 (6-C), 133.20 (7-C), $142.50(3-\mathrm{C})$.

同様な方法によりネロール $(2 \mathrm{~b})$, シトロネロール (2 c), cis-3-ヘキセノール (1 d ), l-メントール (1 e ) からテルペン配糖体 $(3 \mathrm{~b}-\mathrm{e})$ を得た。

ネリルー $\beta-\mathrm{D}$ ーグルコピラノシド $(3 \mathrm{~b})^{17)}$

${ }^{1} \mathrm{H}-\mathrm{NMR}(\delta$, methanol-d 4$): 1.61(3 \mathrm{H}, \mathrm{s}, 9-$ $\left.\mathrm{CH}_{3}\right), 1.68\left(3 \mathrm{H}, \mathrm{s}, 8-\mathrm{CH}_{3}\right), 1.76\left(3 \mathrm{H}, \mathrm{s}, 10-\mathrm{CH}_{3}\right)$, $2.09\left(4 \mathrm{H}, \mathrm{m}, 4.5-\mathrm{CH}_{2}\right), 3.16 \sim 3.41(4 \mathrm{H}, \mathrm{m}, \mathrm{Glu}-$ $2 \sim 5), 3.77(2 \mathrm{H}, \mathrm{d}, \mathrm{d}, \mathrm{Glu}-6), 4.18 \sim 4.37(2 \mathrm{H}, \mathrm{m}$, $\left.1-\mathrm{CH}_{2}\right), \quad 4.29(1 \mathrm{H}, \mathrm{d}, J=7.0 \mathrm{~Hz}, \mathrm{Glu}-1), \quad 5.11$ $(1 \mathrm{H}, \mathrm{t}, 6-\mathrm{C}=\mathrm{CH}), 5.39(1 \mathrm{H}, \mathrm{t}, 2-\mathrm{C}=\mathrm{CH})$.

${ }^{13} \mathrm{C}-\mathrm{NMR}\left(\delta\right.$, methanol- $\left.\mathrm{d}_{4}\right): 18.57(9-\mathrm{C}), 24.46$ (10-C), 26.69 (8-C), 28.51 (4-C), 33.84 (5-C), 63.48 (Glu-6), 67.01 (1-C), 72.37 (Glu-4), 75.82 $(\mathrm{Glu}-2), \quad 78.64 \quad(\mathrm{Glu}-5), \quad 78.87 \quad(\mathrm{Glu}-3), \quad 103.63$ $(\mathrm{Glu}-1), 123.31$ (2-C), 125.77 (6-C), 133.54 (7-C), $142.54(3-\mathrm{C})$.

シトロネリルー $\beta-\mathrm{D}-$ グルコピラノシド (3 c) の物理 定数 ${ }^{1} \mathrm{H}-\mathrm{NMR}$ 及び ${ }^{13} \mathrm{C}-\mathrm{NMR}$ スペクトルは文献值と 一值した ${ }^{18)}$ 。

cis-3-ヘキセニル- $\beta-\mathrm{D}-$ グルコピラノシド $(3 \mathrm{~d})^{19)}$

${ }^{1} \mathrm{H}-\mathrm{NMR}\left(\delta\right.$, methanol- $\left.\mathrm{d}_{4}\right): 0.96(3 \mathrm{H}, \mathrm{t}, 6-$ $\left.\mathrm{CH}_{3}\right), 2.07$ (2 $\mathrm{H}$, quint, $\left.5-\mathrm{CH}_{2}\right), 2.38(2 \mathrm{H}, \mathrm{q}$, $2-\mathrm{CH}_{2}$ ), $3.19(1 \mathrm{H}, \mathrm{t}, \mathrm{Glu}-2), 3.28 \sim 3.37(3 \mathrm{H}, \mathrm{m}$, Glu-3, 4, 5), 3.49 3.89 (4 H, d, d, 1- $\mathrm{CH}_{2}$, Glu-6), $4.28(1 \mathrm{H}, \mathrm{d}, J=7.7 \mathrm{~Hz}, \mathrm{Glu}-1), 5.37 \sim 5.50(2 \mathrm{H}$, $\mathrm{m}, 3,4-\mathrm{CH}=\mathrm{CH})$.

${ }^{13} \mathrm{C}-\mathrm{NMR}\left(\delta\right.$, methanol- $\left.\mathrm{d}_{4}\right): 15.41(6-\mathrm{C}), 22.24$ (5-C), 29.48 (2-C), 63.40 (Glu-6), 71.15 (1-C), 72.23 (Glu-4), 75.71 (Glu-2), 78.53 (Glu-5), 78.71 (Glu-3), 104.97 (Glu-1), 126.55 (3-C), 135.21 $(4-\mathrm{C})$.

$$
\text { メンチルー } \beta-\mathrm{D}-\text { グルコピラノシド }(3 \mathrm{e})^{20)}
$$

${ }^{1} \mathrm{H}-\mathrm{NMR}\left(\delta\right.$, methanol- $\left.\mathrm{d}_{4}\right): 0.78(3 \mathrm{H}, \mathrm{d}, 8-$ $\left.\mathrm{CH}_{3}\right), 0.84\left(3 \mathrm{H}, \mathrm{d}, 10-\mathrm{CH}_{3}\right), 0.89\left(3 \mathrm{H}, \mathrm{d}, 9-\mathrm{CH}_{3}\right)$, 1.18 (1 H, t, 4-CH), 1.24 (1 H, m, 1-CH), 1.59 $1.63\left(4 \mathrm{H}, \mathrm{m}, 5,6-\mathrm{CH}_{2}\right), 2.05(1 \mathrm{H}, \mathrm{m}, 2-\mathrm{CH})$, 2.27 (1 H, quint, 7-CH), 3.11 ( $1 \mathrm{H}, \mathrm{t}, \mathrm{Glu}-2$ ), $3.21 \sim 3.36$ (3 H, m, Glu-3, 4, 5), 3.51 (1 H, dt, 3-CH), 3.71 (2 H, dd, Glu-6), $4.29(1 \mathrm{H}, \mathrm{d}, 7 \mathrm{~Hz}$, Glu-1).

${ }^{13} \mathrm{C}-\mathrm{NMR}\left(\delta\right.$, methanol- $\left.\mathrm{d}_{4}\right): 17.07(8-\mathrm{C}), 22.31$ (10-C), 23.55 (9-C), 24.95 (5-C), 26.90 (7-C), 33.48 (1-C), $36.41(6-\mathrm{C}), 42.40(2-\mathrm{C}), 50.02$ (4-C), 63.78 (Glu-6), $72.60(\mathrm{Glu}-4), 75.71$ (Glu-2), 78.28 (Glu-5), 78.87 (3-C), 79.00 (Glu-3), 102.05 (Glu1).

\section{$2 \cdot 5$ レチノール $(2 \mathrm{f})$ のグリコシル化反応例}

レチノール (2 f) $810 \mathrm{mg}(2.83 \mathrm{mmol})$, テトラーOアセチル $\alpha$-グルコピラノシル = ブロミド (1) $347 \mathrm{mg}$ $(1.00 \mathrm{mmol})$, シリカゲル担持炭酸銀反応剂 $1.21 \mathrm{~g}$ $\left(\mathrm{Ag}_{2} \mathrm{CO}_{3}: 2.05 \mathrm{mmol}\right)$, モレキュラーシーブ $4 \mathrm{~A} 500$ $\mathrm{mg}$ をジエチルエーテル中室温で $24 \mathrm{~h}$ かきまぜた。先 の反応と同様に後処理, 続いて脱アセチル化を行い, シ リカゲルカラムクロマトグラフィー（溶出溶媒, クロロ ホルム : メタノール $=9: 1)$ で精製し, グリコシル化生 成物 (3 f) $139 \mathrm{mg}$ (収率 $32 \%$ ) を単離した。反応生成 物の構造は ${ }^{1} \mathrm{H}-\mathrm{NMR},{ }^{13} \mathrm{C}-\mathrm{NMR},{ }^{1} \mathrm{H}-{ }^{1} \mathrm{H}$ COSY, NOESY スペクトル (Fig.-1), NOE 差スペクトル, COLOC スペクトル (Fig.-2) 及び ${ }^{1} \mathrm{H}-{ }^{13} \mathrm{C}$ COSY ス ペクトル (Fig. -3) により検討した。Fig.ー1 に示した $\mathrm{NOE}$ スペクトルより 18 位のメチル基と 8 位のオレ フィンプロトン, 19 位のメチル基と 7 位のオレフィン プロトン及び 20 位のメチル基 11 位のオレフィンプロト ンの間に NOE が観測された。更に NOE 差スペクトル から 20 位のメチル基と 15 位のメチレンプロトン及び 11 位のオレフィンプロトンの間に NOE が認められ た。これらのことからレチノールのグリコシル化生成物 のオレフィンはオールトランス型構造を有していること が確認された。Fig.-2 に示した COLOC スペクトルか ら第四級炭素の帰属が明らかになった。Fig.ー3に示し た ${ }^{1} \mathrm{H}-{ }^{13} \mathrm{C}$ COSY スペクトルと, 先の $2 \mathrm{D} \mathrm{NMR} \mathrm{スペ}$ クトルの結果から化合物 (3 f) オレフィン炭素部分に関 する㷌属が明らかになった。

\section{レチニルー $\beta$-Dーグルコピラノシド (3 f )}

$[\alpha]_{\mathrm{D}}^{25}-24.8^{\circ}\left(\mathrm{C}=1.01 \mathrm{CH}_{3} \mathrm{OH}\right)$

${ }^{1} \mathrm{H}-\mathrm{NMR}\left(\delta\right.$, methanol- $\left.\mathrm{d}_{4}\right): 0.97(6 \mathrm{H}, \mathrm{s}, 16$, $\left.17-\mathrm{CH}_{3}\right), 1.44\left(2 \mathrm{H}, \mathrm{t}, 3-\mathrm{CH}_{2}\right), 1.57(2 \mathrm{H}, \mathrm{t}, 4-$ $\left.\mathrm{CH}_{2}\right), 1.64\left(3 \mathrm{H}, \mathrm{s}, 18-\mathrm{CH}_{3}\right), 1.82(3 \mathrm{H}, \mathrm{s}, 20-$ $\left.\mathrm{CH}_{3}\right), 1.88\left(3 \mathrm{H}, \mathrm{s}, 19-\mathrm{CH}_{3}\right), 1.95\left(2 \mathrm{H}, \mathrm{t}, 2-\mathrm{CH}_{2}\right)$, $3.14 \sim 3.31$ ( $4 \mathrm{H}, \mathrm{m}, \mathrm{Glu}-2 \sim 5), 3.74(2 \mathrm{H}$, dd, Glu-6), 4.27 (1 H, d, $J=7.7 \mathrm{~Hz}, \mathrm{Glu}-1), 4.40(2 \mathrm{H}$, $\left.\mathrm{dd}, 15-\mathrm{CH}_{2}\right), 5.64(1 \mathrm{H}, \mathrm{t}, 14-\mathrm{CH}), 6.00 \sim 6.09(3 \mathrm{H}$, $\mathrm{m}, 7,8,10-\mathrm{CH}), 6.62(1 \mathrm{H}, \mathrm{d}, 12-\mathrm{CH}), 6.59(1 \mathrm{H}$, 


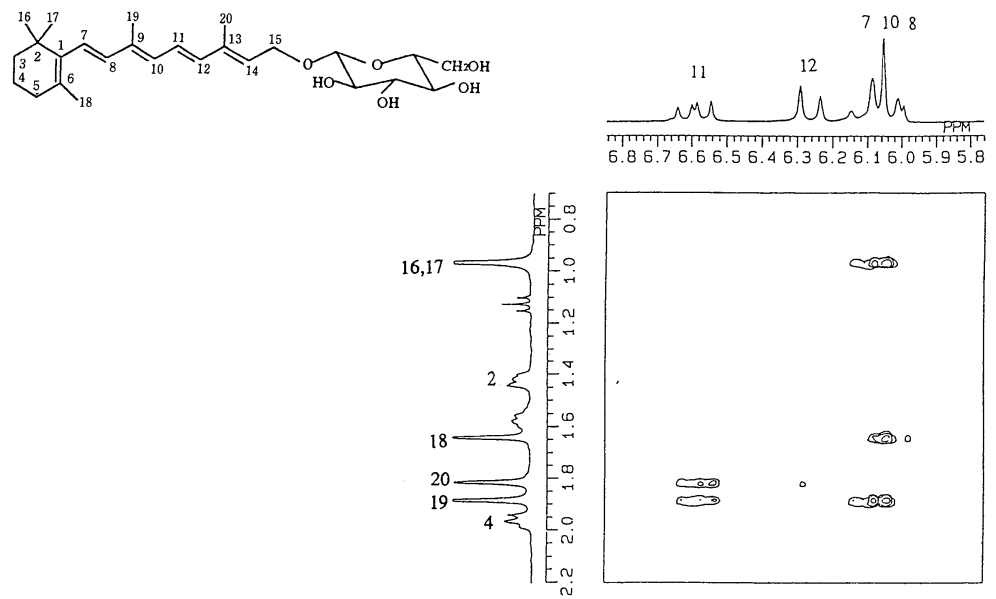

Fig.-1 NOESY spectra of retinyl- $\beta-D^{-}$-glucopyranoside.
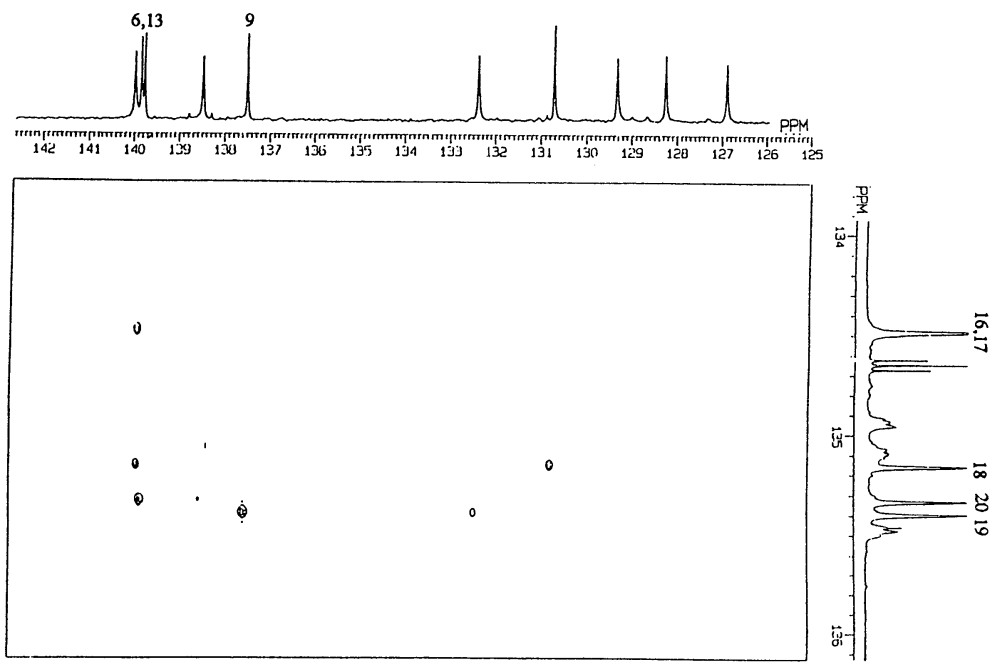

Fig. -2 COLOC spectra of retinyl- $\beta-D^{-}$-glucopyranoside.

$\mathrm{dd}, 11-\mathrm{CH})$.

${ }^{13} \mathrm{C}-\mathrm{NMR}\left(\delta\right.$, methanol-d $\left.\mathrm{d}_{4}\right): 13.61(19-\mathrm{C})$, 13.66 (20-C), 21.09 (3-C), 22.86 (18-C), 30.25 (16, 17-C), 34.67 (4-C), 35.95 (1-C), $41.46(2-\mathrm{C})$, 63.46 (Glu-6), 67.25 (15-C), 72.28 (Glu-4), 75.71 (Glu-2), 78.64 (Glu-5), 78.73 (Glu-3), 103.80 (Glu-1), 126.85 (11-C), $128.22(7-\mathrm{C}), 129.28$ (14C), $130.68(5-\mathrm{C}), 132.35(10-\mathrm{C}), 137.49(9-\mathrm{C})$, 138.42 (12-C), 139.77 (13-C), 139.83 (6-C), 139.99 $(8-\mathrm{C})$.

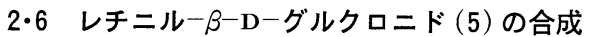

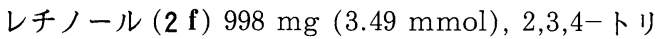
アセチル-1-ブロモーDーグルクロン酸メチル (4) 481 $\mathrm{mg}(1.17 \mathrm{mmol})$, シリカゲル担持炭酸銀反応剂 $1.28 \mathrm{~g}$
$\left(\mathrm{Ag}_{2} \mathrm{CO}_{3}: 2.05 \mathrm{mmol}\right)$, モレキュラーシーブ $4 \mathrm{~A} 500$ $\mathrm{mg}$ をジエチルエーテル中室温で $10 \mathrm{~min}$ かきまぜた 後, $3 \mathrm{~h}$ 加熱還流した。先の反応と同様な方法で後処理 し，続いて脱アセチル化を行い，シリカゲルカラムクロ マトグラフィー（クロロホルム：メタノール=9:1) で 精製し, グルコシル化生成物 (5) $152 \mathrm{mg}$ (収率 $28 \%$ ) を得た。反応生成物の構造は, ${ }^{1} \mathrm{H}-\mathrm{NMR},{ }^{13} \mathrm{C}-\mathrm{NMR}$, ${ }^{1} \mathrm{H}-{ }^{1} \mathrm{H}$ COSY 及び ${ }^{1} \mathrm{H}-{ }^{13} \mathrm{C} \operatorname{COSY}$ スペクトルから決 定した。

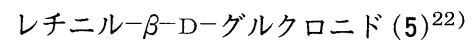

${ }^{1} \mathrm{H}-\mathrm{NMR}\left(\delta\right.$, methanol-d $\left.\mathrm{d}_{4}\right): 0.97(6 \mathrm{H}, \mathrm{s}, 16$, $\left.17-\mathrm{CH}_{3}\right), 1.43\left(2 \mathrm{H}, \mathrm{t}, 3-\mathrm{CH}_{2}\right), 1.57(2 \mathrm{H}, \mathrm{t}, 4-$ $\left.\mathrm{CH}_{2}\right), 1.65\left(3 \mathrm{H}, \mathrm{s}, 18-\mathrm{CH}_{3}\right), 1.80\left(3 \mathrm{H}, \mathrm{s}, 20-\mathrm{CH}_{3}\right)$, $1.89\left(3 \mathrm{H}, \mathrm{s}, 19-\mathrm{CH}_{3}\right), 1.97\left(2 \mathrm{H}, \mathrm{t}, 2-\mathrm{CH}_{2}\right), 3.20$ 

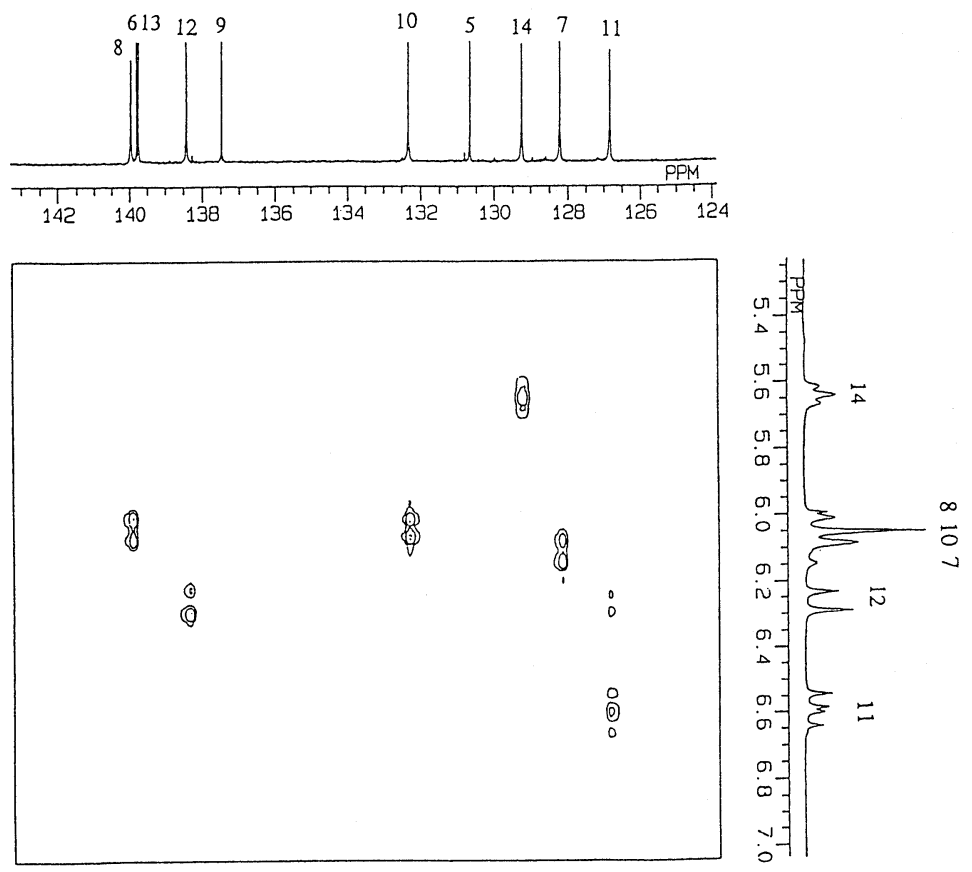

Fig. $-3{ }^{1} \mathrm{H}-{ }^{13} \mathrm{C}$ COSY spectra of retinyl $-\beta-\mathrm{D}-$ glucopyranoside.

(1 H, t, Glu-2), $3.33(1 \mathrm{H}, \mathrm{t}, \mathrm{Glu}-3), 3.70(1 \mathrm{H}, \mathrm{t}$, Glu-4), 3.78 (1 H, d, Glu-5), 4.28 4.40 (2 H, m, $\left.15-\mathrm{CH}_{2}\right), 4.32(1 \mathrm{H}, \mathrm{d}, J=6.6 \mathrm{~Hz}, \mathrm{Glu}-1), 5.62$ $(1 \mathrm{H}, \mathrm{t}, 14-\mathrm{CH}), 6.00 \sim 6.10(3 \mathrm{H}, \mathrm{m}, 7,8,10-\mathrm{CH}=$ C), $6.26(1 \mathrm{H}, \mathrm{d}, 12-\mathrm{CH}=\mathrm{C}), 6.58(1 \mathrm{H}, \mathrm{dd}, 14-$ $\mathrm{CH}=\mathrm{C})$.

${ }^{13} \mathrm{C}-\mathrm{NMR}\left(\delta\right.$, methanol- $\left.\mathrm{d}_{4}\right): 12.76$ (19-C), 12.79 (20-C), 20.32 (3-C), 21.96 (18-C), 29.43 (16, $17-\mathrm{C}), 33.92(4-\mathrm{C}), 35.22(1-\mathrm{C}), 40.73(2-\mathrm{C})$, 66.75 (15-C), 73.08 (Glu-4), 74.68 (Glu-2), 76.82 (Glu-5), 77.28 (Glu-3), 103.55 (Glu-1), 126.27 (11-C), 127.58 (7-C), 128.01 (14-C), 129.99 (5-C), 131.53 (10-C), 136.89 (9-C), 137.59 (12-C), 139.12 (13-C), 139.24 (6-C), 139.35 (8-C), 171.17 (Glu$6)$.

\section{3 結果と考察}

\section{$3 \cdot 1$ テルペンアルコール $(2 \mathrm{a}-\mathrm{e})$ の配糖体の合成}

臭化糖誘導体 (1) とゲラニオール (2 a) のグリコシル 化反応を種々の銀反応剂を用いて検討した結果を Table-1 にまとめた。Koenigs-Knorr 反応の一般的 な反応条件であるジエチルエーテル溶媒中炭酸銀や酸化 銀を用いるグリコシル化により主生成物として $\beta$ 型グリ コシル化アセタートが得られ, 副生成物としてオルトエ ステル体が得られた。この反応は，まず銀化合物と臭化 糖誘導体 (1) の二位のアセチル基の隣接基関与によりア
シロキソニウムイオン中間体を生じ, 次いで求核試薬で あるアルコールの $\mathrm{S}_{\mathrm{N}} 2$ 型反応により $\alpha$ 型グリコシル化 物は得られず $\beta$ 型グリコシル化物が選択的に得られたと 推定される。一方副生成物のオルトエステル体は, 隣接 基関与により生じたアシロキソニウムイオン中間体に, 反応により生じた水やアルコールの攻撃により生じたと 考えている。

炭酸銀や酸化銀の反応剂を用いるゲラニオール (2 a) のグリコシル化反応, 続いて加水分解を行ったのちに得 られたグリコシル化物（3）の全収率は $35 \%$ と $37 \%$ で あった。これら反応剂を用いるグリコシル化反応では, 反応により生成する水の影響のためにグリコシル化生成 物の収率が向上しないのではないかと考え, 水の生じな いサリチル酸銀を調製して，グリコシル化を検討した。 その結果 $\beta$ 型グリコシル化生成物（3 a) の収率は $51 \%$ とかなり向上することが認められた。この反応剂を用い ると, サリチル酸が生成するため反応溶液は酸性にな る。このグリコシル化の反応条件下, サリチル酸程度の 酸に比較的安定なゲラニオールを用いた場合, 炭酸銀や 酸化銀よりサリチル酸銀がよい反応剤になることが分 かった。しかしながらテルペン化合物の中には酸で二重 結合の異性化や環化反応が容易に進行する化合物も多 い。そのため酸触媒やサリチル酸銀を用いるグリコシル 化は，テルペン配糖体の合成に適さない場合も考えられ

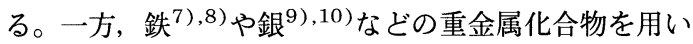
る酸化反応において，無機固体に金属化合物を担持させ 
Table-1 Synthesis of gerany1- $\beta$-D-glucopyranoside (3 a)

\begin{tabular}{|c|c|c|c|c|c|c|c|}
\hline \multirow{2}{*}{$\begin{array}{c}(1) \\
\mathrm{mmol}\end{array}$} & \multirow{2}{*}{$\begin{array}{l}\text { (2 a) } \\
\text { mmol }\end{array}$} & \multicolumn{2}{|l|}{ Acceptor } & \multirow{2}{*}{ Solvent/mL } & \multirow{2}{*}{ Temp. } & \multirow{2}{*}{$\begin{array}{c}\text { Time } \\
\mathrm{h}\end{array}$} & \multirow{2}{*}{$\begin{array}{c}\text { Yield of }(3 \mathrm{a})^{\mathrm{a}} \\
\%\end{array}$} \\
\hline & & & $\left(\mathrm{mmol}^{\mathrm{b}}\right)$ & & & & \\
\hline 1.70 & 2.60 & $\mathrm{Ag}_{2} \mathrm{CO}_{3}$ & $(2.20)$ & Ether/20 & Reflux & 2 & 35 \\
\hline 1.03 & 2.14 & $\mathrm{Ag}_{2} \mathrm{O}$ & $(1.30)$ & Ether/10 & Reflux & 2 & 37 \\
\hline 1.00 & 2.01 & Ag Salicylate & $(1.20)$ & Ether/10 & Reflux & 1.5 & 51 \\
\hline 1.00 & 1.55 & $\mathrm{Ag}_{2} \mathrm{CO}_{3}-\mathrm{SiO}_{2}$ & $(1.20)$ & Ether/5 & Reflux & 3 & 53 \\
\hline 1.00 & 1.60 & $\mathrm{Ag}_{2} \mathrm{O}-\mathrm{SiO}_{2}$ & $(1.20)$ & Ether/5 & Reflux & 3 & 54 \\
\hline 1.00 & 1.50 & $\mathrm{Ag}$ Silicate- $-\mathrm{SiO}_{2}$ & $(1.20)$ & Ether $/ 5$ & Reflux & 3 & 58 \\
\hline 1.01 & 1.56 & $\left.\mathrm{Ag}_{2} \mathrm{CO}_{3}-\mathrm{Al}_{2} \mathrm{O}_{3} \mathrm{c}\right)$ & $(1.20)$ & Ether $/ 5$ & Reflux & 3 & 53 \\
\hline 1.00 & 1.53 & $\mathrm{Ag}_{2} \mathrm{CO}_{3}-$ Cerite & $(1.21)$ & Ether/5 & Reflux & 3 & 47 \\
\hline 1.00 & 1.50 & $\mathrm{Ag}_{2} \mathrm{CO}_{3}-\mathrm{SiO}_{2}$ & $(1.23)$ & $\mathrm{CH}_{2} \mathrm{Cl}_{2} / 3$ & r.t. & 12 & 50 \\
\hline 1.01 & 1.52 & $\mathrm{Ag}$ Silicate- $-\mathrm{SiO}_{2}$ & $(1.20)$ & $\mathrm{CH}_{2} \mathrm{Cl}_{2} / 3$ & r.t. & 12 & 56 \\
\hline
\end{tabular}

a) Yield of the isolated product was calculated based on the used bromide (1).

b) Molar quantity of the $\mathrm{Ag}$ compound for the bromide (1).

c) Activated neutral $\mathrm{Al}_{2} \mathrm{O}_{3}$ (Merck Art. 1097, 70 230 mesh) was used.

Table-2 Synthesis of terpenyl- $\beta-D-$ glucopyranoside (3).

\begin{tabular}{|c|c|c|c|c|c|c|c|c|}
\hline \multirow{2}{*}{ Terpene alcohol } & \multirow[b]{2}{*}{ mmol } & \multirow{2}{*}{$\begin{array}{c}(1) \\
\mathrm{mmol}\end{array}$} & \multicolumn{2}{|c|}{ Acceptor } & \multirow{2}{*}{$\begin{array}{l}\text { Solvent } \\
/ \mathrm{mL}\end{array}$} & \multirow{2}{*}{ Temp. } & \multirow{2}{*}{$\begin{array}{c}\text { Time } \\
\mathrm{h}\end{array}$} & \multirow{2}{*}{$\begin{array}{c}\text { Yield of }(3)^{a)} \\
\%\end{array}$} \\
\hline & & & & $\left(\mathrm{mmol}^{\mathrm{b})}\right)$ & & & & \\
\hline Nerol & (2 b) 1.50 & 1.00 & $\mathrm{Ag}_{2} \mathrm{CO}_{3}-\mathrm{SiO}_{2}$ & $(2.20)$ & Ether $/ 5$ & Reflux & 2 & 56 \\
\hline Citronellol & (2 c) 1.53 & 1.00 & $\mathrm{Ag}_{2} \mathrm{CO}_{3}-\mathrm{SiO}_{2}$ & $(2.20)$ & Ether $/ 5$ & Reflux & 2 & 57 \\
\hline cis-3-Hexenol & (2 d) 1.53 & 1.00 & $\mathrm{Ag}_{2} \mathrm{CO}_{3}-\mathrm{SiO}_{2}$ & $(2.20)$ & Ether/5 & Reflux & 2 & 52 \\
\hline$l$-Menthol & $(2 \mathrm{e}) 1.53$ & 1.00 & $\mathrm{Ag}_{2} \mathrm{CO}_{3}-\mathrm{SiO}_{2}$ & $(2.20)$ & Ether/5 & Reflux & 2 & 26 \\
\hline
\end{tabular}

a) Yield of the isolated product was calculated based on the used bromide (1).

b) Molar quantity of the Ag compound for the bromide (1).

ると生成物の収率や選択性が向上し，さらに反応生成物 之酸化剤の分離が容易になるなどの特徴が現れるため固 体担持反応剂や活性化剂の開発や応用が種々検討されて いる。そこでシリカゲル，アルミナ及びセライトなどの 無機固体物質に炭酸銀や酸化銀などの銀化合物を担持さ せた反応剂を調製し，臭化糖誘導体 (1) とゲラニオール (2 a)のグリコシル化を詳細に検討した。その結果無機 固体に担持させた銀化合物を反応郕として用いた場合, $\beta$ 型グリコシル化生成物（3 a) が収率 47 ～58 \% で得ら れ，反応剂として炭酸銀や酸化銀を単独に用いる場合よ りかなり収率が向上することが認められた。またこのよ うな固体担持銀反応剂を用いるとオルトエステル体の副 生はほとんど認められなかった。シリカゲルやアルミナ 担持炭酸銀反応剂はセライト担持炭酸銀反応剂よりもや や $\beta$ 型グリコシル化生成物 (3 a) の生成に効果のあるこ とが認められた。これはシリカゲルとゲラニオールの水 素結合の形成やアルミナと銀反応剂の関与によるアシロ キソニウムイオンの安定化などの効果がグリコシル化反 応に寄与して収率が向上したものと推定している。ケイ 酸銀反応剂を用いた場合は, $\beta$ 型グリコシル化生成物 $(3$ a)が収率 $58 \%$ で得られた。

次に種々のテルペンアルコール (2), すなわちネロー ル (2 b), シトロネロール (2 c), cis-3-ヘキセノール (2 d) 及びlーメントール (2 e) に対して, 反応が中性条 件を示したシリカゲルやアルミナ担持炭酸銀反応剂を用 いグリコシル化を検討した。これらの結果を Table-2 にまとめた。ネロール (2 b), シトロネロール (2 c), cis-3-へキセノール (2d) を用いた場合はそれぞれ収

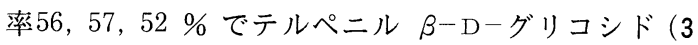
b-d)が得られた。しかしながらl一メントール (2 e)の 場合, グリコシル化物 (3e).が収率 $26 \%$ で得られた。 これは, メントールが第二級アルコールであるため立体 障害が影響しているものと考えている。

\section{$3 \cdot 2$ レチノール $(2 \mathrm{f})$ の配糖体の合成}

Koenigs-Knorr 反応の一般的な反応条件であるジ エチルエーテル溶媒中炭酸銀や酸化銀を用いたレチノー ル（2f) のグリコシル化反応ではグリコシル化生成物 (3 f) は得られず，原料を回収した $($ Table-3)。またこの 反応においてジェチルアニリンを反応剂とする場合や, テトラヒドロフランを溶媒に用いた文献記載のグリコシ 
Table-3 Synthesis of retinyl- $\beta-\mathrm{D}-$ glucopyranoside (3 f ) and retinyl- $\beta-\mathrm{D}-$ glucocuronide (5)

\begin{tabular}{|c|c|c|c|c|c|c|c|}
\hline \multirow{2}{*}{$\begin{array}{l}\text { Retinol (2 f ) } \\
\text { mmol }\end{array}$} & \multirow{2}{*}{$\begin{array}{c}\text { (1) or (4) } \\
\text { mmol }\end{array}$} & \multicolumn{2}{|l|}{ Acceptor } & \multirow{2}{*}{$\begin{array}{c}\text { Ether } \\
\mathrm{mL}\end{array}$} & \multirow{2}{*}{ Temp. } & \multirow{2}{*}{$\begin{array}{c}\text { Time } \\
\mathrm{h}\end{array}$} & \multirow{2}{*}{$\begin{array}{c}\text { Yield of }(3 \mathbf{f}) \text { or }(5)^{a)} \\
\%\end{array}$} \\
\hline & & & $\left(\mathrm{mmol}^{\mathrm{b})}\right)$ & & & & \\
\hline 5.59 & (1) 0.97 & $\mathrm{Ag}_{2} \mathrm{CO}_{3}$ & $(5.02)$ & 5 & Reflux & 6 & tr. \\
\hline 2.97 & (1) 1.01 & $\mathrm{Ag}_{2} \mathrm{CO}_{3}-\mathrm{SiO}_{2}$ & $(2.00)$ & 5 & Reflux & 3 & 30 \\
\hline 3.03 & (1) 1.00 & $\mathrm{Ag}_{2} \mathrm{CO}_{3}-\mathrm{Al}_{2} \mathrm{O}_{3}{ }^{\mathrm{c})}$ & $(2.05)$ & 5 & Reflux & 3 & - \\
\hline 2.95 & (1) 1.01 & $\mathrm{Ag}_{2} \mathrm{CO}_{3}-\mathrm{Al}_{2} \mathrm{O}_{3}{ }^{\mathrm{d})}$ & $(2.04)$ & 5 & Reflux & 3 & 26 \\
\hline 2.98 & (1) 1.00 & $\mathrm{Ag}_{2} \mathrm{CO}_{3}-$ Celite & $(2.05)$ & 5 & Reflux & 3 & 20 \\
\hline 2.83 & (1) 1.00 & $\mathrm{Ag}_{2} \mathrm{CO}_{3}-\mathrm{SiO}_{2}$ & $(2.05)$ & 5 & r. t. & 24 & 32 \\
\hline 3.49 & (4) 1.17 & $\mathrm{Ag}_{2} \mathrm{CO}_{3}-\mathrm{SiO}_{2}$ & $(2.05)$ & 5 & Reflux & 3 & 28 \\
\hline
\end{tabular}

a) Yield of the isolated product was calculated based on the used bromide (1) or (4).

b) Molar quantity of the $\mathrm{Ag}$ compound for the bromide (1) or (4).

c) Activated neutral $\mathrm{Al}_{2} \mathrm{O}_{3}$ (Merck Art. 1097, 70 230 mesh) was used.

d) Activated basic $\mathrm{Al}_{2} \mathrm{O}_{3}$ (Merck Art. 1076, 70 230 mesh) was used.

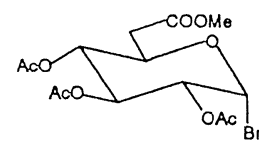

(4)

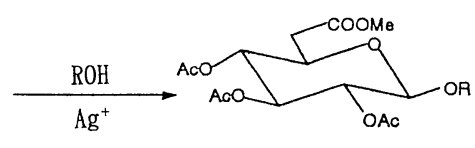

$\mathrm{ROH}(2 f): \mathrm{R}=$ Retinyl

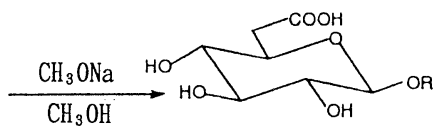

(5)

Scheme-2

ル化法 ${ }^{21)}$ を検討したが生成物（3 f ）はほとんど得られ なかった。しかしながらシリカゲルやアルミナ担持炭酸 銀反応剂を用いた場合, グリコシル化生成物 (3 f ) が収 率32〜26\%で得られた (Table-3)。レチノールのグリ コシル化は, ゲラニオールの反応の場合と異なった傾向 が認められた。塩基性アルミナ担持炭酸銀反応剤を用い た反応ではグリコシル化生成物（3f f) が収率 $26 \%$ で, セライト担持炭酸銀反応剤では収率 $20 \%$ で得られた。 しかしながらシリカゲル担持炭酸銀反応剂を用いた反応 では, グリコシル化生成物（3 f) の収率は 32 30\% 之, 収率の向上が認められた。なお中性アルミナ担持炭 酸銀反応剂を用いた反応では，生成物は得られず原料を 回収した。このように炭酸銀を単独に用いるよりシリカ ゲル担持炭酸銀を反応剤として用いた場合, 収率の向上 が認められた。

合成したグリコシル化生成物 (3 f ) のレチニル基部分 の立体構造は ${ }^{1} \mathrm{H},{ }^{1} \mathrm{H}-{ }^{1} \mathrm{H}$ NOESY, ${ }^{1} \mathrm{H}-{ }^{13} \mathrm{C}$ COSY, COLOC 及び NOE 差 NMR スペクトル (Fig.-1〜3) などによりオールトランス型のオレフィン構造を有して いることを確認した。

レチノールは脂溶性ビタミンとして動物の成長に必須 な化合物である。合成したグリコシル化生成物（3 f $)$ は, 糖が結合したことにより水溶性となる。この水溶性 のビタミン A の特性を生かした応用については現在検 討中である。
次にレチニルー $\beta-D$-グルクロニド (5) の合成を検討 した。この化合物 (5) は胆汁中に見いだされ，ヒト血中 に存在する内因性定常成分で, 白血病やがんの予防薬 になることが見いだされ，注目されている化合物であ

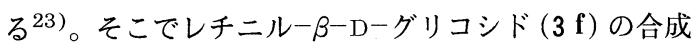
において反応剂として効果が認められたシリカゲル担持 炭酸銀反応剂と臭化グルクロン酸誘導体 (4) を用いて検

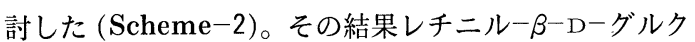
ロニド (5) を収率 $28 \%$ で合成することができた $(\mathrm{Ta}$ ble-3)。このようにして合成したグリコシル化生成物 (5)の構造は ${ }^{1} \mathrm{H}$, NOESY, ${ }^{1} \mathrm{H}-{ }^{13} \mathrm{C}$ COSY,${ }^{1} \mathrm{H}-{ }^{13} \mathrm{C}$ COLOC 及び NOE 差 NMR スペクトルなどの解析, 更

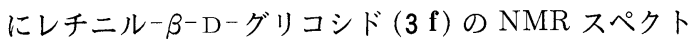
ルの解析結果との比較などからオールトランス型オレ フィン構造であることを確認した。またこの化合物の構 造は文献 ${ }^{22)}$ の分析結果ともよく一致した。なおこの化 合物 (5) は, ジエチルエーテル溶媒中炭酸銀を用いる Koenigs-Knorr 反応により収率 $15 \%$ で合成した報告 がある ${ }^{22)}$ 。本報告のようにグリコシル化反応にシリカ ゲル担持炭酸銀反応剂を用いると担持固体の効果が発揮 され，グリコシル化生成物の収率が向上することが認め られた。

\section{謝 辞}

本研究の一部は明治大学科学技術研究所の研究助成を 受けて行ったものであり、ここに期して謝意を表す。 
〔平成 5 年 (1993 年) 7 月 5 日受理〕

\section{文献}

1) 村上孝夫, “天然物の構造と化学”, 広川書店 (1982) p. 43

2）後藤良造, 猪川三郎, 世良 明, 大谷晋一, “単糖類の 化学”，丸善 (1988) p. 165

3) 榊原敏之, 油化学, 39, 451 (1990)

4) 厚藤伸吉, 森島直彦, 膳 昭之助, 有合化, 41, 701 (1983)

5）津々美秀雄, 石戸良治, 有合化, 38, 473 (1980)

6) I.E. Ackermann, D.V. Banthorpe, W.D. Fordham, J. P. Kinder, I. Poots, Liebigs Ann. Chem., 1989, 79

7) E. Keinan, Y. Mazur, J. Org. Chem., 43, 1020 (1978)

8) T.C. Jempty, K.A. Gogins, Y. Mazur L.L. Miller, J. Org. Chem., 46, 4545 (1981)

9) M. Fetizon, M. Golfier, J-M. Louis, J. Chem. Soc., Chem. Comm., 1969, 1118

10) V. Balogh, M. Fetizon, M. Golfier, J. Org. Chem., 36, 1339 (1971)

11) R.L. Whistler, M.L. Wolform, "Methods in Carbohydrate Chemistry", Academic Press Inc., New
York (1966) Vol. II, p. 221

12) H. Horster, K. Stopp, Planta Med, 29, 208 (1976)

13) M. Strscey, J. Chem. Soc., 1939, 1529

14) H. Paulsen, O. Lockhoff, Chem. Ber., 114, 3102 (1981)

15) G. Wulff, G. Rohle, W. Kruger, Chem. Ber., 105 1097 (1972)

16) K.E.A. Ishag, H. Jork, M. Zeppezauer, Fresenius Z. Anal. Chem., 321, 331 (1985)

17) P.J. Williams, C.R. Strauss, B. Wilson, R.A.M Westropp, Phytochemstry, 21, 2013 (1982)

18) H. Paulsen, B. Le-Nguyen, V. Sinnwell, V. Heemann, F. Seehofer, Liebigs Ann. Chem., 1985, 1513

19) K. Mizutani, M. Yuda, O. Tanaka, Y. Saruwatari, T. Fuwa, M-R. Jia, Y-K Ling, X-F. Pu, Chem. Pharm. Bull., 36, 2689 (1988)

20）阪田 功, 東山龍雄, 岩村 俶, 小清水弘一, 香料, 130, 79 (1981)

21）高林 昇, 大橋清信, 橋場義正, 特許公報, 昭 4520097 (1970)

22) A.B. Barua, J.A. Olson, Biochem. J., 244, 231 (1987)

23）日本ビタミン学会編, “ビタミンハンドブック 1, 脂溶性 ビタミン”, 化学同人 (1989) p. 11 